\title{
Existence of Hepatitis B Surface Protein Mutations and Other Variants: Demand for Hepatitis B Infection Control in Cambodia
}

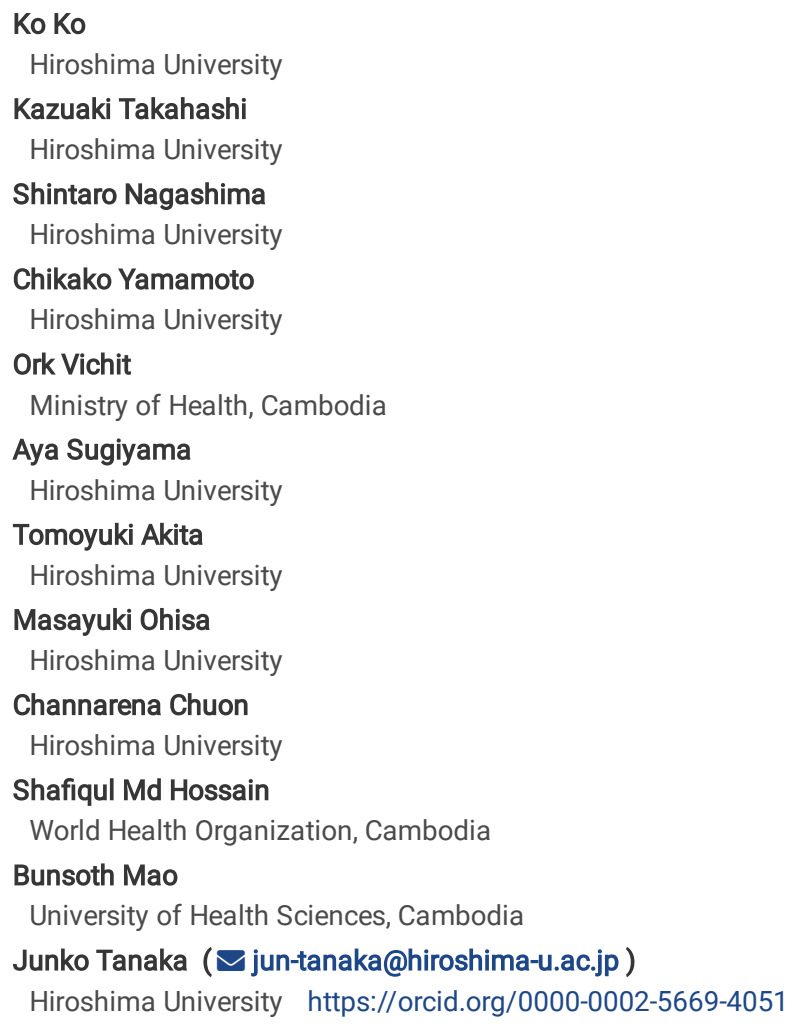

Version of Record: A version of this preprint was published at BMC Infectious Diseases on April 25th, 2020. See the published version at https://doi.org/10.1186/s12879-020-05025-3. 


\section{Abstract}

Aims

This study aimed to detect Hepatitis B virus (HBV) genome sequences and their variants as of nationwide scale using dried blood spot (DBS) samples and to provide up-to-date reference data for infection control and surveillance in Cambodia.

Method

Among 2,518 children age 5-7 years and their 2,023 mothers participated in 2017 Cambodia nationwide sero-survey on hepatitis B surface antigen (HBsAg) prevalence using multistage random sampling strategy, 95 mothers and 13 children positive to HBsAg were included in this study. HBV DNA was extracted from DBS, then performed polymerase chain reaction. HBV genotypes and potential variants were examined by partial and full length genomic analysis.

Results

HBV DNA positive rate was $3.46 \%(70 / 2023)$ in mothers and $0.48 \%(12 / 2518)$ in their children. Genotype $\mathrm{C}(80.49 \%)$ was abundantly found throughout the whole Cambodia whilst genotype B (19.51\%) was exclusively found in regions bordering Vietnam. HBs mutants were found in $24.29 \%$ of mothers and $16.67 \%$ of children with HBV DNA positive sera. Full-length genome analysis revealed the homology of $99.62-100 \%$ in each mother-child pair. Genotype B was clarified to recombinant genotype B4/C2 and B2/C2. Double (48.39\%) and combination mutation (32.26\%) were observed in core promoter region of HBV C1 strains.

\section{Conclusion}

This study showed the capable of DBS for large-scale molecular epidemiological study of HBV in resource limited countries. Full-genome sequences yield the better understanding of sub-genotypes, their variants and the degree of homology between strains isolated from mother-child pairs calls for effective strategies on prevention, control and surveillance of mother-to-child HBV transmission in Cambodia.

\section{Background}

Viral hepatitis infection including hepatitis B virus (HBV) is still challenging as the public health concern, having global prevalence of $3.5 \%$ and 1.34 million deaths in 2015[1]. The prevalence of HBV infection might differ in each World Health Organization (WHO) region[2] and the high prevalence of 6.1\% and 6.2\% were found in Africa and Western Pacific region respectively[1]

Although the gross decrement of HBV prevalence was reported in the developed countries after discovery of effective hepatitis B vaccine (HepB) since 1981[3], the prevalence is still high in developing countries. Mother-to-child transmission (MTCT), also known as vertical transmission, still ranks as the main route of HBV transmission in intermediate and high endemic countries. Cambodia, one of the developing countries in WHO Western Pacific Region, has been reported high hepatitis B surface antigen (HBsAg) prevalence ranging from 7.7-13\%[4, 5]. In 2005, Cambodia started phasing-in HepB vaccine to National Immunization programme (NIP) and the coverage was achieved over $90 \%$ since 2008[6]. After introduction of HepB vaccine in the whole Cambodia, HBsAg prevalence among $\leq 5$ years old children markedly reduced to $3.5 \%$ in 2006 [7] and then dropped to $0.33 \%-3.45 \%$ in three provinces of Cambodia in 2011 [5] Recent nationwide study on HBsAg prevalence among mother-child pairs in 2017 revealed the positive rate of $0.56 \%$ among children and $4.39 \%$ among their mothers [8]. Very low HBsAg positive rate in children with its reciprocal high positive rate in mothers indicates the needs for further study on HBV in Cambodia. Moreover, the clinical outcomes of chronic HBV infection rely on HBV genotypes and sub-genotype as viral factor. Understanding HBV genotypes and subgenotypes can predict not only liver disease progression but also the response to antiviral treatment[9]. Although there were only a few reports about HBV genotype distribution in Cambodia $[4,10]$, the nationwide distribution pattern of HBV genotypes was still unknown in Cambodia.

Additionally, the widespread use of HepB vaccine in combating HBV infection potentially threatens the emergence of mutant strains at hepatitis B surface gene. The mutation in HBs gene causes the amino acid substitution either single or multiple mutations in surface protein especially a determinant region between amino acid 120 and 147 and mutation in this region reduces the sensitivity to diagnostic test, failure of response to both HepB vaccine and HBIG [11]. It is later denoted as vaccine escapes mutation and is abundantly occurred in those children who had received plasma-derived vaccines $(0.3 \%)$ rather than recombinant vaccines (0.06\%)[12]. The emergence of vaccine escapes mutants threatens the efficacy of HepB vaccine among infants and now raising as the public health concern in elimination pathway of HBV. Cambodia has a long track of using HepB vaccine over a decade and there is no study on HBs mutation meanwhile.

Therefore, this study aimed to detect HBV genome sequences and their potential mutant strains specifically mutation at surface antigen as of nationwide scale using dried blood spot (DBS) samples and then to provide the up-to-date reference data for consideration of prevention, control and surveillance of HBV infection in Cambodia.

\section{Methods}

Subjects of the study

This is the nationwide sero-epidemiological study on HBsAg prevalence among 5-7 years old children and their mothers from 25 provinces of the whole Cambodia in 2017 using the multistage stratified random sampling strategy. Its study designs has been introduced previously[8] and results of HBV prevalence from this study had been accepted by WHO Western Pacific Regional Office. Dried blood spot (DBS) using HemaSpot ${ }^{\mathrm{TM}}$ (Spot on Science Inc., Austin, USA) samples were collected from 2,520 children and their 2,028 mothers but two children DBS samples and five mothers' DBS samples were excluded for their insufficient amount of blood for measurement. Therefore, a total of 4,541 DBS samples (2,518 children and 2023 mothers) were tested for HBsAg 
(Lumipulsell $\circledast$ HBsAg, Fujirebio, Japan with reported sensitivity of $100 \%$ and specificity of $99.7 \%[13]$ ) by chemiluminescent enzyme immunoassay (CLEIA) using Lumipulse G1200 (Fujirebio Inc, Japan) with cut-off value of 1.0. The reported sensitivity and specificity of HBV DNA using DBS was 95\% (95\% Cl: 8399) and 99\% (95\% Cl: 53-100), respectively [14]. The vaccination history was taken from yellow book (the vaccination records) provided by Ministry of Health of Cambodia. The recall memory on vaccination status was also taken from the parents or guardians of those children whose yellow books were not present. Nucleic Acid Extraction

HemaSpot ${ }^{\text {TM }}$ contains 8 fins of filter papers and the nucleic acid was directly extracted from one fin of HBsAg positive DBS samples using SMITEST EX-R\&D (Medical and Biological Laboratories co., LTD, MA, USA) strictly following the manufacturer's instruction. The final pellets highly concentrated with nucleic acid were then suspended in $50 \mu$ l of distilled water and then performed the polymerase chain reaction (PCR).

Partial And Full-length Genomes Sequencing

For full-length genome sequences, the same primers as of the previously described method were used in this study $[15,16]$. The amplification was carried out by Nested Polymerase Chain Reaction (Nested-PCR) using Prime STARßGXL polymerase (Takara Bio Inc., Shiga, Japan) and the primer set A (WA-L and WA-R and inner primers WA-L2 and WA-R2)[15]. For the missing portion of the circular HBV DNA, the extracted DNA was assigned again for the nested PCR using Prime STAR®GXL polymerase (Takara Bio Inc., Shiga, Japan) and the primer set B (S1, S2, AS1, and AS2). The obtained PCR product was directly sequenced using a 3730xI DNA sequencer (Thermo Fisher Scientific K.K., Kanagawa, Japan) and the BigDye Terminator v3.1 Cycle Sequencing Kit (Applied Biosystems, Foster City, CA, USA).

The samples which were not detected by WA primer set, were then attempted for s-region fragment (partial genome sequence) using the primer set \#S1-1 and \#S1-2 and the inner primers \#S2-1 and \#S2-2[17, 18]. The obtained PCR products were directly sequenced as the same way mentioned in full length sequences.

Molecular Evolutionary Analysis

The sequence data were analyzed by GENTYX-MAC Version 18 software (Genetyx Corporation, Tokyo, Japan). Genotypes B1-B9 and C1-C16 obtained from GenBank were assigned as reference standard strains for sequencing. The further analysis of genotype $\mathrm{C} 1$ was done by the neighbor-joining method[19] and then the evolutionary analysis of Texa was employed in MEGA7[20].

Detection Of HBV Genome Recombination

The recombination of circular HBV DNA was detected using the SimPlot program and boost scanning analysis[21] with jumping profile Hidden Markov Model (jpHMM) for recombination detection in circular genomes[22]. $11 \mathrm{HBV}$ genotype B strains from this study were employed for the determination of HBV genome recombination and visualized in a circular form using the software package Circos [23].

Statistical Analysis

The statistical analysis was performed using JMP version 10 (SAS Institute Inc., Cary, NC). The $\chi^{2}$ and Fisher's exact test were used appropriately to compare between groups. The statistical significance was set at $\mathrm{p}<0.05$.

\section{Results}

Study participants

Of 2023 mothers and 2518 children aged 5-7 years, HBsAg positive DBS samples from 95 mothers (4.7\%) and 13 children (0.5\%) were included. The mean age of mothers was $32.36 \pm 6.01$ years. $69.2 \%$ of children were 5 years old and $30.8 \%$ were 6 years old. Among 95 HBsAg positive mothers, nine of their children were positive for HBsAg giving the vertical transmission rate of $9.5 \%$ (9/95). The detail of background demography were already discussed by Vichit et al[8]. In this study, we will present the outcomes from genome sequences analysis.

Nucleic Acid Extraction And HBV Genomes Amplification

HBV DNA amplified by WA region primer set was detected in 52 samples (41 mothers and 11 children) from which the full genome sequences having 3 kilo base pairs (3kbp) could perform in $78.1 \%(32 / 41)$ of mothers and $90.9 \%(n=10 / 11)$ of children. After another trial of amplification to those samples undetected by WA primers, the partial sequencing using s-region primers was achieved in the HBV DNA positive samples of 29 mothers and 1 child. Therefore, HBV DNA was extracted from $73.7 \%$ (70/95) of mothers and $92.3 \%(12 / 13)$ of children who were positive for HBsAg and all these 82 samples were able to classify HBV genotypes in Cambodia. The overall HBV DNA positive rate was 3.5\% (70/2023) in mothers and 0.5\% (12/2518) in children. (Table 1)

\section{Due to technical limitations, Table 1 is provided in the Supplementary Files section.}

Nationwide HBV Genotype Distribution And Phylogenetic Tree

HBV genotype was determined by the s-region of each detected strain using the neighbor-joining method. HBV genotype $\mathrm{C}$ was abundantly found in $84.3 \%$ $(59 / 70)$ of mothers and $58.3 \%$ (7/12) of children. HBV genotype B was found in $15.7 \%$ of mothers (11/70) and $36.3 \%$ of children (5/12). As the phylogenetic tree was constructed by the strains having 823 base pairs from nt111-nt933, 53 out of 82 HBV DNA positive samples could assign. Almost all HBV genotype $\mathrm{C}$ were sub-grouped to $\mathrm{C} 1$ and were gathered in the same cluster of China, Hong Kong, Thailand, Laos, Malaysia, Myanmar and India except one (C173433) 
which is sub-genotype C 8 and is much closed to Indonesian strain (Fig. 1). Only a small portion of HBV genotype B was circulated in Cambodia and is in the same cluster to Vietnam in phylogenetic tree except one (C170329) which is adjacent to Taiwanese strain (Fig. 1).

Homology Of Genome Sequences In 7 Mother-child Pairs

Of 9 HBsAg positive mother-child pairs, 2 pairs were excluded for mothers' refusal to participate. Among them, only one pair could amplify 2630 bp. The rate of base sequences match (homology) in six mother-child pairs ranged from 99.62 to $100 \%$. The analysis of 2630 bp (nt1929-nt1343) detected from one mother-child pair (C171408m and C171407c) showed a 99.96\% homology in their nucleotide sequence. (Table 2)

Table 2

Homology of the detected full length HBV strains isolated from 6 mother-child pairs Identity (\%)

\begin{tabular}{|c|c|c|c|c|c|c|c|c|c|c|}
\hline $\begin{array}{l}\text { Isolate } \\
\text { Name }\end{array}$ & $\mathrm{C} 171228 \mathrm{c}$ & $\mathrm{C} 171229 \mathrm{~m}$ & $\mathrm{C} 171360 \mathrm{c}$ & $\mathrm{C} 171361 \mathrm{~m}$ & $\mathrm{C} 174334 \mathrm{c}$ & $\mathrm{c} 174335 \mathrm{~m}$ & $\mathrm{C} 174347 \mathrm{c}$ & C174348m & C174492c & C174493m \\
\hline $\begin{array}{l}\text { gC1 } \\
\text { C171229m }\end{array}$ & 99.62 & & & & & & & & & \\
\hline $\begin{array}{l}\text { gC1 } \\
\text { C171360c }\end{array}$ & 98.53 & 98.25 & & & & & & & & \\
\hline $\begin{array}{l}\text { gC1 } \\
\text { C171361m }\end{array}$ & 98.35 & 98.25 & 99.78 & & & & & & & \\
\hline $\begin{array}{l}\text { gB4/C } \\
\text { C174334c }\end{array}$ & 91.91 & 92.02 & 91.84 & 91.78 & & & & & & \\
\hline $\begin{array}{l}\mathrm{gB} 4 / \mathrm{C} \\
\mathrm{C} 174335 \mathrm{~m}\end{array}$ & 91.94 & 92.05 & 91.87 & 91.81 & 99.9 & & & & & \\
\hline $\begin{array}{l}\mathrm{gB} 4 / \mathrm{C} \\
\mathrm{C} 174347 \mathrm{c}\end{array}$ & 91.75 & 91.93 & 91.69 & 91.63 & 98.25 & 98.28 & & & & \\
\hline $\begin{array}{l}\text { gB4/C } \\
\text { C174348m }\end{array}$ & 91.78 & 91.96 & 91.72 & 91.66 & 98.28 & 98.32 & 99.96 & & & \\
\hline $\begin{array}{l}\text { gC1 } \\
\text { C174492c }\end{array}$ & 98.38 & 98.25 & 98.22 & 98.25 & 92.06 & 92.09 & 92.03 & 92.6 & & \\
\hline $\begin{array}{l}\text { gC1 } \\
\text { C174493m }\end{array}$ & 98.38 & 98.25 & 98.22 & 98.25 & 92.06 & 92.09 & 92.03 & 92.6 & 100 & \\
\hline $\begin{array}{l}\text { gC1 } \\
\text { C174537c }\end{array}$ & 98.5 & 98.16 & 98.56 & 98.41 & 91.81 & 91.85 & 91.75 & 91.81 & 98.28 & 98.28 \\
\hline $\begin{array}{l}\text { gC1 } \\
\text { C174538m }\end{array}$ & 98.47 & 98.13 & 98.53 & 98.44 & 91.78 & 91.81 & 91.72 & 91.75 & 98.25 & 98.25 \\
\hline
\end{tabular}

The base sequence of the detected HBV strains from 6 mother-child pairs has homology from 99.62-100\%.

Analysis of up to $2630 \mathrm{bp}$ (nt1929-nt1343) detected from the mother (C171408m) and child (C171407c) showed a 99.96\% homology in the nucleotide seque gC1: HBV sub-genotype C1, gB4/C: recombinant HBV genotype B4/C, The isolate ID ends in " $m$ " represents for mother and that ends in " $c$ " represents for chilc

Occurrence Of HBs Mutant Strains In Cambodia

The determination of mutation was confined to the area specific for "a determinant region of hepatitis B surface antigen (nt121- nt149)[24]. HBs mutant strains were detected in 17 mothers and 2 children and were recognized at P120S, T/I126N, P127S/T/A, T131I/N, M133T, F134 and G145R/A. In children, one for each aa120 (P120S) and aa127 (P127S) were found (Table 3). But in mothers, the predominant mutation was found at aa127 (P127S/T/A: 5/17) and aa131 (T131I/N/P: 4/17) and aa145 (G145R/A: 4/17), aa126 (T/I126N: 3/17) and aa133 (M133T: 3/17), aa134 (F134L: 1/17) (Fig. 2). The overall HBsAg mutation rate among HBV DNA positive sera was $24.3 \%(17 / 70)$ in mothers and $16.7 \%(2 / 12)$ in children $(p=0.5657)$. The HBs mutation rate by the entire participants was $0.8 \%(17 / 2023)$ in mothers and $0.08 \%(2 / 2518)$ in children $(p<0.001)$. Among 17 mothers infected with HBs mutant, two children $(11.7 \%)$ were found to be HBsAg positive. Among 53 mothers infected with wild type HBV, 7 children (13.2\%) were positive to HBsAg (Table 4, Fig. 2). 
Table 3

HBV Genotype, Mutation and Vaccination status of 13 HBsAg positive children and their mothers

\begin{tabular}{|c|c|c|c|c|c|c|c|c|c|c|c|}
\hline & & Children & & & & & Mother & & & & \\
\hline No. & Province & $\begin{array}{l}\text { Sample } \\
\text { ID }\end{array}$ & $\begin{array}{l}\text { HBV } \\
\text { DNA }\end{array}$ & Genotype & Mutation & $\begin{array}{l}\text { Vaccination } \\
\text { status }\end{array}$ & Sample ID & HBsAg & $\begin{array}{l}\text { HBV } \\
\text { DNA }\end{array}$ & Genotype & Mutation \\
\hline 1. & Pursat & $\mathrm{c} 171228 \mathrm{c}$ & + & C & - & 3 Penta & c171229m & + & + & $\mathrm{C}$ & G145R \\
\hline 2. & $\begin{array}{l}\text { Kampong } \\
\text { Thom }\end{array}$ & c174492c & + & $\mathrm{C}$ & P127S & 3 Penta & c174493m & + & + & $\mathrm{C}$ & P127S \\
\hline 3. & $\begin{array}{l}\text { Tboung } \\
\text { Khmum }\end{array}$ & c174334c & + & $\mathrm{B} / \mathrm{C}$ & P120S & $\begin{array}{l}\text { HB-BD + } \\
3 \text { Penta }\end{array}$ & c174335m & + & + & $\mathrm{B} / \mathrm{C}$ & - \\
\hline 4. & $\begin{array}{l}\text { Preah } \\
\text { Sihanouk }\end{array}$ & $c 174425 c$ & + & $\mathrm{B} / \mathrm{C}$ & - & $\begin{array}{l}\text { HB-BD + } \\
3 \text { Penta }\end{array}$ & c174426m & - & - & - & - \\
\hline 5. & Phnom Penh & $\mathrm{c} 171360 \mathrm{c}$ & + & $\mathrm{C}$ & - & No vaccination & c171361m & + & + & C & - \\
\hline 6. & Ratanak Kiri & c172147c & + & $\mathrm{C}$ & - & No vaccination & c172148m & - & - & - & - \\
\hline 7. & Stung Treng & c173863c & + & $\mathrm{C}$ & - & No vaccination & c173864m & + & + & $\mathrm{C}$ & - \\
\hline 8. & Preah Vihear & c174537c & + & $\mathrm{C}$ & - & No vaccination & c174538m & + & + & $\mathrm{C}$ & - \\
\hline 9. & $\begin{array}{l}\text { Kampong } \\
\text { Speu }\end{array}$ & c171407c & + & $\mathrm{C}$ & - & $\begin{array}{l}\text { HB-BD + } \\
2 \text { Penta }\end{array}$ & c171408m & + & + & $\mathrm{C}$ & - \\
\hline 10. & $\begin{array}{l}\text { Tboung } \\
\text { Khmum }\end{array}$ & c174347c & + & $\mathrm{B} / \mathrm{C}$ & - & $\begin{array}{l}\text { HB-BD + } \\
3 \text { Penta }\end{array}$ & c174348m & + & + & $\mathrm{B} / \mathrm{C}$ & - \\
\hline 11. & Ratanak Kiri & c172153c & ND & & & No vaccination & c172154m & + & + & $\mathrm{C}$ & - \\
\hline 12. & Svay Rieng & c171594c & + & $\mathrm{B} / \mathrm{C}$ & - & $\begin{array}{l}\text { HB-BD + } \\
3 \text { Penta }\end{array}$ & \multicolumn{5}{|c|}{ Not participated } \\
\hline 13. & Phnom Penh & c171367c & + & $\mathrm{B} / \mathrm{C}$ & - & 1 Penta & \multicolumn{5}{|c|}{ Not participated } \\
\hline
\end{tabular}


Table 4

"a" determinant Variants of Mother and their corresponding child's HBV and Immunization status

\begin{tabular}{|c|c|c|c|c|c|c|c|c|c|c|c|}
\hline \multicolumn{5}{|l|}{ Mother } & \multicolumn{6}{|l|}{ Child } & \multirow{2}{*}{$\begin{array}{l}\text { Notes } \\
\text { Reported Function }\end{array}$} \\
\hline Isolate ID & $\begin{array}{l}\text { Age } \\
\text { class }\end{array}$ & $\begin{array}{l}\text { HBsAg/ } \\
\text { Anti- } \\
\text { HBs }\end{array}$ & $\begin{array}{l}\text { Genotype/ } \\
\text { sub- } \\
\text { genotype }\end{array}$ & Mutant & Isolate ID & Age & $\begin{array}{l}\text { HBsAg/ } \\
\text { Anti- } \\
\text { HBs }\end{array}$ & $\begin{array}{l}\text { Genotype/ } \\
\text { sub- } \\
\text { genotype }\end{array}$ & Mutant & $\begin{array}{l}\text { HB- } \\
\text { BD/ } \\
\text { Penta }\end{array}$ & \\
\hline C174493m & $\begin{array}{l}40- \\
49\end{array}$ & $+/-$ & $\mathrm{C} 1$ & P127S & $\mathrm{C} 174492 \mathrm{c}$ & 5 & $+/-$ & $\mathrm{C} 1$ & P127S & $-/ 3$ & $\begin{array}{l}\text { Altered hydrophilicity, } \\
\text { electrical charge and } \\
\text { acidity of the loop }\end{array}$ \\
\hline C171229m & $\begin{array}{l}30- \\
39\end{array}$ & $+/-$ & $\mathrm{C} 1$ & G145R & $\mathrm{C} 171228 \mathrm{c}$ & 5 & $+/-$ & $\mathrm{C} 1$ & - & $-/ 3$ & Vaccine Escapes Mutant \\
\hline C170329 & $\begin{array}{l}30- \\
39\end{array}$ & $+/-$ & $\mathrm{B} 2 / \mathrm{C} 2$ & M133T & $\mathrm{C} 170328$ & 6 & $-/+$ & - & - & $+/ 3$ & Rescue of virion secretion \\
\hline C171039 & $\begin{array}{l}30- \\
39\end{array}$ & $+/-$ & ${ }^{\dagger} \mathrm{B}$ & M133T & C171038 & 6 & $-/+$ & - & - & $+/ 3$ & Rescue of virion secretion \\
\hline C171118 & $\begin{array}{l}20- \\
29\end{array}$ & $+/-$ & ${ }^{\dagger} \mathrm{C}$ & $\begin{array}{l}\text { T131N, } \\
\text { M133T }\end{array}$ & C171117 & 5 & $-/$ & - & - & $+/ 3$ & $\begin{array}{l}\text { Rescue of virion secretion, } \\
\text { Rescue of virion secretion }\end{array}$ \\
\hline C171550 & $\begin{array}{l}20- \\
29\end{array}$ & $+/-$ & $\mathrm{C} 1$ & G145A & C171549 & 6 & $-/+$ & - & - & $-/ 3^{\ddagger}$ & Vaccine Escapes Mutant \\
\hline C172116 & $\begin{array}{l}20- \\
29\end{array}$ & $+/-$ & $\mathrm{C} 1$ & P127A & C172115 & 6 & $-/$ & - & - & $+/ 1^{\ddagger}$ & Unclear \\
\hline C173073 & $\begin{array}{l}30- \\
39\end{array}$ & $+/-$ & ${ }^{\dagger} \mathrm{C}$ & $1126 \mathrm{~N}$ & C173072 & 5 & $-/$ & - & - & $+/ 3$ & Vaccine Escapes Mutant \\
\hline C173429 & $\begin{array}{l}20- \\
29\end{array}$ & $+/-$ & ${ }^{\dagger} \mathrm{C}$ & $\mathrm{P} 127 \mathrm{~T}$ & C173428 & 6 & $-/+$ & - & - & $-/ 3^{\ddagger}$ & Unclear \\
\hline C173706 & $\begin{array}{l}30- \\
39\end{array}$ & $+/-$ & ${ }^{+} \mathrm{C}$ & $\begin{array}{l}\text { P127T, } \\
\text { G145R }\end{array}$ & C17305 & 5 & $-/$ & - & - & $+/ 3^{\ddagger}$ & $\begin{array}{l}\text { Unclear, } \\
\text { Vaccine Escapes Mutant }\end{array}$ \\
\hline C173764 & $\begin{array}{l}20- \\
29\end{array}$ & $+/-$ & $\mathrm{C} 1$ & F134L & C173763 & 5 & $-/+$ & - & - & $+/ 3$ & $\begin{array}{l}\text { Lower reactivity in HBsAg } \\
\text { assay }\end{array}$ \\
\hline C173866 & $\begin{array}{l}20- \\
29\end{array}$ & $+/-$ & $\mathrm{C} 1$ & $\mathrm{P} 127 \mathrm{~T}$ & C173865 & 6 & $-/+$ & - & - & $\mathrm{NA} / 3^{\ddagger}$ & Unclear \\
\hline C174337 & $\begin{array}{l}30- \\
39\end{array}$ & $+/+$ & $\mathrm{C} 1$ & $\begin{array}{l}\text { T131P, } \\
\text { G145R }\end{array}$ & C174336 & 6 & $-/+$ & - & - & $+/ 3$ & $\begin{array}{l}\text { Unclear, } \\
\text { Vaccine Escapes Mutant }\end{array}$ \\
\hline C174478 & $\begin{array}{l}20- \\
29\end{array}$ & $+/+$ & $\mathrm{C} 1$ & T131। & C174477 & 6 & $-/+$ & - & - & $+/ 3$ & $\begin{array}{l}\text { Altered hydrophilicity, } \\
\text { electrical charge and } \\
\text { acidity of the loop }\end{array}$ \\
\hline C174483 & $\begin{array}{l}20- \\
29\end{array}$ & $+/-$ & ${ }^{\dagger} \mathrm{C}$ & $1126 \mathrm{~N}$ & C174482 & 5 & $-/$ & - & - & $+/ 2$ & Vaccine Escapes Mutant \\
\hline C174269 & $\begin{array}{l}30- \\
39\end{array}$ & $+/+$ & ${ }^{\dagger} \mathrm{C}$ & $1126 \mathrm{~N}$ & C174268 & 5 & $-/+$ & - & - & $+/ 3$ & Vaccine Escapes Mutant \\
\hline C170464 & $\begin{array}{l}30- \\
39\end{array}$ & $+/-$ & ${ }^{\dagger} \mathrm{C}$ & $\mathrm{T} 131 \mathrm{~N}$ & C170463 & 5 & $-/$ & - & - & $+/ 3$ & Rescue of virion secretion \\
\hline
\end{tabular}

HBsAg prevalence and HBs mutation rate among immunized children were $0.4 \%$ and $0.08 \%$ and that among non-immunized children were $4.8 \%$ and $0 \%$ respectively. The a determinant mutation rate among children infected from mother with mutant variant is higher than those infected from mother with wild type (5.9\% Vs $1.9 \%)$. If the child received HB-BD within 24 hours after birth, the infection rate among children with mutant variants is ( $2 \%$ Vs $4.5 \%)$. By each genotype, the mutation rate in genotype $C$ was $24.2 \%(16 / 66)$ and that of genotype $B$ was $18.8 \%(3 / 16)$.

Characteristics of HBs mutant strains found among 13 mother-child pairs

After excluding children with undetectable HBV DNA $(n=1)$, whose mothers' HBsAg negative $(n=2)$ and whose mothers refused to participate ( $n=2), 8$ mother-child pairs were then analyzed for HBs mutation. One mother-child pair has mutation at nt127 (P127S) in both mother and her child, one mother-child pair had mutation at nt120 (P120S) only in child and another one pair has mutation at nt145 (G145R) only in mother. Seven out of 13 children had completed at least 2 doses of pentavalent vaccine with or without HB-BD. (Fig. 2)

Double and combination mutant strains among children and their mothers in Cambodia 
The double mutation at A1762T/G1764A was found only in HBV genotype $\mathrm{C} 1$ strains (12 mothers and 3 children) with the mutation rate of $48.39 \%$. The combination mutation at C1653T and A1762T/G1764A or T1753C and A1762T/G1764A was also only found in HBV genotype C1 strains (10 mothers) with the mutation rate of $32.26 \%$. (Table 5 ) 
Table 5

Demography and Characteristic of 42Cambodian strains with mutation in Enhancer II and Core Promoter region

\begin{tabular}{|c|c|c|c|c|c|c|c|c|c|}
\hline \multirow[t]{2}{*}{ No. } & \multirow[t]{2}{*}{ Isolate Name } & \multirow[t]{2}{*}{ Age class } & \multirow[t]{2}{*}{ Residence } & \multirow[t]{2}{*}{ Genotype } & \multirow[t]{2}{*}{ Length (bp) } & \multirow[t]{2}{*}{ Pres Deletion } & \multicolumn{3}{|c|}{ Enhancer II and Core Promoter } \\
\hline & & & & & & & 1653 & 1753 & $1762 / 1764$ \\
\hline 1. & $\mathrm{C} 171361 \mathrm{~m}$ & $20-29$ & $\mathrm{PP}$ & $\mathrm{C} 1$ & 3215 & & $(+)$ & & \\
\hline 2. & $\mathrm{C} 171360 \mathrm{c}$ & $0-9$ & PP & $\mathrm{C} 1$ & 3215 & & & & $(+)$ \\
\hline 3. & $\mathrm{C} 174538 \mathrm{~m}$ & $20-29$ & PV & $\mathrm{C} 1$ & 3215 & & $(+)$ & & $(+)$ \\
\hline 4. & C174537c & $0-9$ & PV & $\mathrm{C} 1$ & 3215 & & & & $(+)$ \\
\hline 5. & $\mathrm{C} 171229 \mathrm{~m}$ & $30-39$ & PS & $\mathrm{C} 1$ & 3170 & $(+)$ & & & \\
\hline 6. & $\mathrm{C} 171228 \mathrm{c}$ & $0-9$ & PS & $\mathrm{C} 1$ & 3215 & & & & $(+)$ \\
\hline 7. & $\mathrm{C} 174493 \mathrm{~m}$ & $40-49$ & KT & $\mathrm{C} 1$ & 3215 & & & & \\
\hline 8. & C174492c & $0-9$ & $\mathrm{KT}$ & $\mathrm{C} 1$ & 3215 & & & & \\
\hline 9. & $\mathrm{C} 174335 \mathrm{~m}$ & $30-39$ & TK & $\mathrm{B} 4 / \mathrm{C} 2$ & 3215 & & & & \\
\hline 10. & $\mathrm{C} 174334 \mathrm{c}$ & $0-9$ & TK & $\mathrm{B} 4 / \mathrm{C} 2$ & 3215 & & & & \\
\hline 11. & C174348m & $30-39$ & TK & $\mathrm{B} 4 / \mathrm{C} 2$ & 3215 & & & & \\
\hline 12. & $\mathrm{C} 174347 \mathrm{c}$ & $0-9$ & TK & $\mathrm{B} 4 / \mathrm{C} 2$ & 3215 & & & & \\
\hline 13. & C171459 & $30-39$ & PP & $\mathrm{C} 1$ & 3194 & & & $(+)$ & $(+)$ \\
\hline 14. & $\mathrm{C} 171060$ & $20-29$ & $\mathrm{KD}$ & $\mathrm{C} 1$ & 3215 & & $(+)$ & & $(+)$ \\
\hline 15. & C172116 & $20-29$ & $\mathrm{KC}$ & $\mathrm{C} 1$ & 3215 & & & & \\
\hline 16. & C172168 & $20-29$ & $\mathrm{KC}$ & $\mathrm{C} 1$ & 3191 & $(+)$ & & & \\
\hline 17. & C173909 & $20-29$ & $\mathrm{KC}$ & $\mathrm{C} 1$ & 3215 & & & $(+)$ & $(+)$ \\
\hline 18. & C170492 & $30-39$ & $\mathrm{KS}$ & $\mathrm{C} 1$ & 3215 & & & & \\
\hline 19. & C171046 & $30-39$ & KS & $\mathrm{C} 1$ & 3215 & & & & \\
\hline 20. & C172562 & $20-29$ & KS & $\mathrm{B} 4 / \mathrm{C} 2$ & 3215 & & & & \\
\hline 21. & C170405 & $40-49$ & $\mathrm{KCh}$ & $\mathrm{B} 4 / \mathrm{C} 2$ & 3215 & & & $(+)$ & \\
\hline 22. & C171573 & $40-49$ & $\mathrm{KCh}$ & $\mathrm{C} 1$ & 3215 & & & $(+)$ & $(+)$ \\
\hline 23. & C173681 & $30-39$ & $\mathrm{KCh}$ & $\mathrm{C} 1$ & 3227 & & & & \\
\hline 24. & $\mathrm{C} 174314$ & $30-39$ & $\mathrm{KCh}$ & $\mathrm{C} 1$ & 2961 & $(+)$ & & & \\
\hline 25. & C173866 & $20-29$ & ST & $\mathrm{C} 1$ & 3215 & & & & $(+)$ \\
\hline 26. & C171550 & $20-29$ & SR & $\mathrm{C} 1$ & 3158 & $(+)$ & & & \\
\hline 27. & C174478 & $20-29$ & $\mathrm{OM}$ & $\mathrm{C} 1$ & 3215 & & & & \\
\hline 28. & C173275 & $30-39$ & TA & $\mathrm{C} 1$ & 3161 & $(+)$ & & $(+)$ & $(+)$ \\
\hline 29. & C171728 & $20-29$ & PS & $\mathrm{C} 1$ & 3196 & & & & \\
\hline 30. & C172920 & $30-39$ & $\mathrm{KT}$ & $\mathrm{C} 1$ & 3215 & & & & \\
\hline 31. & C173764 & $20-29$ & $\mathrm{KT}$ & $\mathrm{C} 1$ & 3173 & $(+)$ & $(+)$ & & $(+)$ \\
\hline 32. & C173334 & $30-39$ & BT & $\mathrm{C} 1$ & 3215 & & & & $(+)$ \\
\hline 33. & C172749 & $30-39$ & BT & $\mathrm{C} 1$ & 3215 & & & $(+)$ & $(+)$ \\
\hline 34. & C171026 & $30-39$ & BT & $\mathrm{C} 1$ & 3215 & & & & $(+)$ \\
\hline 35. & $\mathrm{C} 173400$ & $40-49$ & BT & $\mathrm{C} 1$ & 3215 & & & & \\
\hline 36. & C170329 & $30-39$ & SRi & $\mathrm{B} 2 / \mathrm{C} 2$ & 3215 & & & & \\
\hline 37. & C174337 & $30-39$ & TK & $\mathrm{C} 1$ & 3194 & $(+)$ & $(+)$ & & $(+)$ \\
\hline
\end{tabular}

PP: Phnom Penh, PV: Preah Vihear, PS: Pursat, KT: Kampong Thom, TK: Tboung Khmum, KD: Kandal, KC: Kracheh, KS: Kampong Speu, KCh: Kampong Cham, ST: Stung Treng, SR: Siem Reap, Sri: Svay Rieng, OM: Otdar Meanchey, TA: Takeo, BT: Battambang, RK: Ratanak Kiri, PSi: Preah Sihanouk, "M": Male, "F": Female, "C1": hepatitis B virus subgenotype $\mathrm{C} 1$, "B/C" : hepatitis B virus recombinant B/C, " $(+)$ " indicates mutation occur in the core promoter, PreC and Core regions. 


\begin{tabular}{|c|c|c|c|c|c|c|c|c|c|}
\hline \multirow[t]{2}{*}{ No. } & \multirow[t]{2}{*}{ Isolate Name } & \multirow[t]{2}{*}{ Age class } & \multirow[t]{2}{*}{ Residence } & \multirow[t]{2}{*}{ Genotype } & \multirow[t]{2}{*}{ Length (bp) } & \multirow[t]{2}{*}{ Pres Deletion } & \multicolumn{3}{|c|}{ Enhancer II and Core Promoter } \\
\hline & & & & & & & 1653 & 1753 & $1762 / 1764$ \\
\hline 38. & C170337 & $20-29$ & SRi & $\mathrm{B} 4 / \mathrm{C} 2$ & 3215 & & & & \\
\hline 39. & $\mathrm{C} 171367 \mathrm{c}$ & $0-9$ & PP & $\mathrm{B} 4 / \mathrm{C} 2$ & 3239 & & & & \\
\hline 40. & C172147c & $0-9$ & RK & $\mathrm{C} 1$ & 3215 & & & & \\
\hline 41. & $\mathrm{C} 174425 \mathrm{c}$ & $0-9$ & PSi & $\mathrm{B} 4 / \mathrm{C} 2$ & 3215 & & & & \\
\hline 42. & C171594c & $0-9$ & SRi & $\mathrm{B} 4 / \mathrm{C} 2$ & 3215 & & & & \\
\hline
\end{tabular}

Full-length Genome Sequences And Evolutionary Analysis Of Texa

We could do the full-genome sequences in 42 samples (32 mothers and 10 children) with the nucleotide length from 3161-3239 base pairs amongst which 31 strains were belong to genotype $\mathrm{C}$ and the rest (11 strains) were genotype $\mathrm{B}$. All HBV genotype $\mathrm{C}$ belongs to sub-genotype $\mathrm{C} 1$ which were assumed to be originated from Indonesia, Thailand, India, China and Vietnam. For HBV genotype B, almost all detected strains $(n=10)$ are found to be recombinant genotype B4/C2. Only one strain (C170329) showed recombinant B2/C2. All these recombinant B/C strains build up with circular DNA mixing up of sequences resembling genotype $B$ and a short portion of genotype $C$ in core region (Fig. 3) with various breaking points for recombination. By mean of evolutionary relationship of Texa, all recombinant genotype B4/C2 strains are near to Vietnamese strains but B2/2C is very near to Taiwanese strain.

\section{Discussion}

This study is the first report to present HBV DNA positive rate, its amplification rate, genotype distribution and existence of potential HBV variants among the strains isolated from mother-child pairs in Cambodia as of its nationwide scale.

The overall HBV DNA positive rate in children was $0.48 \%$ which definitely reflects the well-established vaccination program in Cambodia. But, the vertical transmission rate was $9.47 \%$ (9/95) which is higher than the previously reported rate among vaccinated Asian (2-3\%) [25]. The homology between HBV strains isolated from these mother-child pairs was $99.62-100 \%$ which strongly indicated that the transmission was vertical.

The genome sequences revealed the genotype distribution pattern of HBV in the whole Cambodia. HBV genotype C was abundantly found in almost all provinces of Cambodia except Kandal, Campong Cham, Tbong Kmoun and Svay Rieng provinces where HBV genotype B was predominant. Some studies also reported that genotype $\mathrm{C}$ is the predominant genotype in Cambodia and then followed by genotype $\mathrm{B}[10,26]$. Cambodia is bordered by Thailand to the northwest, Laos to the northeast, and Vietnam to the east and the Gulf of Thailand to the southwest. The genotype distribution pattern is linked to the neighboring countries of Cambodia. In our study, HBV genotype B was exclusively circulated in Svay Rieng, Kampot and Tbong Kmoun provinces; the border regions to the Vietnam where HBV genotype B is predominant (72.6\%); particularly sub-genotype B4 (87.8\%) [27]. HBV genotype C was abundantly found in the Stung Treng, Ratanakiri and Preah Vihear provinces, the northeast part of Cambodia and border region to Laos, where HBV genotype $\mathrm{C}$ (55.4\%) is also predominant [28]. Meanwhile, in Oddar, Meanchey, Pursat and Battambang provinces; the west and northwest regions of Cambodia bordering to Thailand, HBV genotype $C$ was exclusively found where $73-87.5 \%$ of the detected HBV strains were genotype $C[29,30]$. In fact, HBV genotypes B and C are the most prevalent types in Asia and the genotype $\mathrm{C}$ has more pathogenicity in compared with genotype $\mathrm{B}$ [31]. By this study, it is supposed to have the historical relation of HBV genotype between Cambodia and its neighboring countries. Therefore, this nationwide genotype distribution pattern raises two important issues for the infection control of HBV in Cambodia. Firstly, the health sector should be aware of geographic variation of HBV genotypes and its historical relation among neighboring countries and should consider for implementation of effective HBV preventive strategies among migrants from both sides. Secondly, the reported predominant genotypes and sub-genotypes of our study can be the clue for better understanding of viral factors on liver disease progression in chronic hepatitis B carriers in Cambodia.

HBs mutant strains were isolated from 17 mothers and 2 children. The overall HBs mutation rate among HBV DNA positive sera was $23.94 \%$ in mothers and $18.18 \%$ in children, $24.24 \%$ in genotype $\mathrm{C}$ and $18.75 \%$ in genotype $\mathrm{B}$. This rate was lower than that reported from Singapore (39\%) [32] but is higher than Thailand (22.4\%)[33] and Malaysia (9\%)[34]. By this study, high HBs mutation rate among mother-child pairs of Cambodia suggested the potential spread of vaccine escapes mutant strains in Cambodia. HBs mutation specifically a mutant was occurred most frequently among immunized children and who received plasma derived HepB vaccine[12] and the similar results were found among immunized children of our study but there was no statistically significance. The vaccine itself driven HBs mutation through immune pressure causing amino acid substitution and point mutation[35] although we could not exclude the vertical transmission of HBs mutants.

In our study, only 2 out of 17 children born to mothers with HBs mutants became infected and both of them did not receive HB-BD. But, no infection was found if the children received HB-BD. This could be explained by the hypothesis, that the HBs mutant strain itself has lower replication rate and also has negative effect on replication of wild type HBV in mixed infection through high T cell immune response causing less infectivity and transmissibility of HBV infection[36]. If the child had received HB-BD within 24 hours, the vaccine totally interrupts the vertical transmission. If the child missed HB-BD, it causes high possibility of vertical transmission despite previous study reported on low level of viral replication among mutant strains. Although it was not clear whether 
HBs mutants were transmitted vertically or only under immune pressure due to vaccination in our study and the number of isolated mutant strains was quite small to compare, it was revealed that HB-BD is crucial for preventing vertical transmission of HBV either wild type or HBs mutants.

HBs mutation was profoundly occurred in genotype $\mathrm{C}$ in our study than genotype B. In fact, genotype B was documented to have high potential for occurrence of amino acid substitution than genotype C[37]. This discrepancy might be due to difference genotype distribution pattern. But the existence of HBs mutants in Cambodia alarms the possible breakthrough infection among immunized children which may threaten the long term effect of massive immunization. Despite the successful establishment of HepB vaccination, Cambodia has no specific program and protocol for PMTCT of HBV until now. It is challenging for Cambodia on its pathway to meet WHO's viral hepatitis elimination goal of by 2030 . Therefore, the health sector should develop and disseminate the national guideline, HBV screening, assurance of HB-BD administration to all newborns within 24 hours after delivery and provide specific anti-viral treatment to HBV carrier mothers.

Apart from HBs mutation, preS deletion (22.58\%), double (48.39\%) and combination mutation (32.26\%) were also found in HBV genotype C1 strains. In fact, HBV genotype $\mathrm{C}$ can easily mutate[38] and its mutation is significantly related to the HCC occurrence[10, 26, 39]. In our study, although we could not correlate the mutant variant with respective liver disease condition, based on recently published study [39], it indicates the need of proper counseling, early and proper referral to the specialized center, assessment for eligibility to anti-viral therapy and regular follow-up care which should be offered to them even they are currently asymptomatic.

This study used the DBS samples to detect not only the HBV sero-markers but also HBV DNA and consequently both partial and full length genome sequences, which is the critical tool for the advanced molecular epidemiology. According to recent systematic review and meta-analysis report, the pooled estimate of sensitivity and specificity for HBV-DNA using DBS was 95\% (95\% Cl: 83-99) and 99\% (95\% Cl: 53-100), respectively[14]. Despite the whole blood samples by venipuncture still ranks as the gold standard for biological specimen, this study proved the capable of DBS for HBV full-length genomes sequences and it is useful as alternative blood collection tool for large scale molecular epidemiological study especially in resources limited countries which may accelerate the surveillance of target virus.

The limitations were present in this study. Firstly, our study could not evaluate the HBs mutation rate by type of HepB vaccine used in the children. Secondly, the study is cross-sectional so that the investigation of liver disease stages and their progress is impossible. Based on the previous study, we could only suggest that HBV C1infected participants of our study have high possibility to HCC occurrence[39]. At last, even we used DBS samples for detection of partial and full-length HBV genome sequence; we could not compare it with gold standard venous blood samples. Further comparative study on detection of viral genomes in both DBS and venous samples is needed.

\section{Conclusion}

A partial and full-length HBV genomes sequences are able to extract from dried blood spot samples which confer up to molecular epidemiological study of HBV. HBV Genotype $C$ is predominant type in Cambodia but the genotype $B$ is exclusively found in the regions border to Vietnam which shows the historical relation of HBV across the border regions. The recombinant sub-genotype B/C and HBs mutant variants later known as vaccine escapes mutation (among HBV DNA positive sera, $24.29 \%$ in mothers and $16.67 \%$ in children, $24.24 \%$ in genotype $C$ and $18.75 \%$ in genotype B) were found by this study. The double (48.39\%) and combination mutation (32.26\%) in HBV C1 strains of this study also alarm for the high possibility of hepatocellular carcinoma in individuals with chronic hepatitis B. Therefore, our finding strongly calls for implementation of effective countermeasure and its surveillance on viral hepatitis including PMTCT so that Cambodia can continue straightforwardly to meet WHO's elimination goal of viral hepatitis by 2030.

\section{List Of Abbreviations}

HBV, Hepatitis B virus; DBS, Dried Blood Spot samples; HBV DNA, Hepatitis B Deoxyribonucleic acid; HIV, Human Immunodeficiency Virus; WHO, World Health Organization; HepB, Hepatitis B vaccine; HBsAg, Hepatitis B surface Antigen; NIP, National Immunization Program; MTCT, Mother-to-child transmission; PMTCT, Prevention of Mother-to-child transmission; HBIG, Hepatitis B Immunoglobulin; CLEA, Chemiluminescent Enzyme Immunoassay; PCR, Polymerase chain reaction; HB-BD, Hepatitis B birth-dose

\section{Declarations}

\section{Ethics approval and consent to participate}

Written informed consent was obtained from the mother for her child and herself; if the mother was absent, the father or other caretaker was asked to provide written informed consent for the child. Informed assent was obtained from all children in the study. All specimens and questionnaire data were de-identified, with reference only to a unique identifier. The study protocol was approved by the Cambodia National Ethics Committee for Human Research (392NECHR), the Ethics Review Committee for the WHO Western Pacific Region and the Ethical Committee for Epidemiology of Hiroshima University (E-573) and the study procedure strictly followed the Declaration of Helsinki for research including human beings.

\section{Consent for publication}

Not applicable

\section{Availability of data and materials}


The dataset used and analysed during the current study is available from the corresponding author. The full and partial sequences of HBV strain isolated in this study are registered to GenBank via DDBJ. The sequences can be assessed at http://getentry.ddbj.nig.ac.jp/top-e.html once the paper is published.

\section{Competing Interests}

The authors declare no conflict of interests.

Funding

This study was financially supported by.

1) Japanese Ministry of Health, Labour and Welfare (H28-Kansei-Japan-001)

2) Project Research Centre for epidemiology and prevention of viral hepatitis and hepatocellular carcinoma, Hiroshima University, Japan (Director: J. Tanaka)

3) World Health Organization: The Expanded Programme on Immunization (EPI).

4) Viral hepatitis Research Foundation of Japan (AAOHELP: Asia-Africa-Oceania Hepatitis Experts Linkage Promotion)

Role of the funding sources

The funders of the study had no role in study design, data collection, data analysis, data interpretation, or writing of the report. The corresponding author has full access to all the data in the study and has final responsibility for the decision to submit for publication.

\section{Authors Contributions}

Prof. Junko Tanaka had full access to all data in the study and took responsibility for the integrity of the data and the accuracy of the data analysis. Study concept and design: JT. Management of study implementation: JT, OV, SHM, AS, SN. Training of field staff: SN, CY, CC. Conducting and monitoring the study MB, KK, CC, MO, TA. Data management and Data analysis: KT, KK, AS, MO. Interpretation of data: JT, KT, KK, TA. Manuscript development: KK, JT, KT. Critical revision of the manuscript for important intellectual content: KK, JT. All authors approved the final version of the manuscript.

\section{Acknowledgements}

Our thanks will go to each and every mother and child for their actively participation in this study. We also thank to Chiyoko Kuroda and Chitomi Aratani, laboratory technicians from department of Epidemiology, Infectious Disease Control and Prevention, Hiroshima University, for their kind support during laboratory measurement.

\section{References}

1. World_Health_Organization: Global hepatitis report, 2017. In.; 2017: 83.

2. World_Health_Organization: WHO definition of regional grouping. In.; 2017.

3. Szmuness W, Stevens CE, Zang EA, Harley EJ, Kellner A: A controlled clinical trial of the efficacy of the hepatitis B vaccine (heptavax B): A final report. Hepatology 1981, 1(5):377-385.

4. Sa-Nguanmoo P, Tangkijvanich P, Thawornsuk N, Vichaiwattana P, Prianantathavorn K, Theamboonlers A, Tanaka Y, Poovorawan Y: Molecular epidemiological study of hepatitis B virus among migrant workers from Cambodia, Laos, and Myanmar to Thailand. J Med Viro/ 2010, 82(8):1341-1349.

5. Mao B, Patel MK, Hennessey K, Duncan RJW, Wannemuehler K, Soeung SC: Prevalence of chronic hepatitis B virus infection after implementation of a hepatitis B vaccination program among children in three provinces in Cambodia. Vaccine 2013, 31(40):4459-4464.

6. UNICEF WHOa: World Health Organization and UNICEF estimate of immunization coverage. In.; 2014.

7. Soeung SC, Rani, M.V., Huong, V.T., Sarath, S., Kimly, C., \& Kohei, T. : Results from nationwide hepatitis B serosurvey in Cambodia using simple and rapid laboratory test: implications for National Immunization Program. The American joumal of tropical medicine and hygiene, 81 2, $252-7$. 2009.

8. Ork V, Woodring J, Shafiqul Hossain M, Wasley A, Nagashima S, Yamamoto C, Chuon C, Sugiyama A, Ohisa M, Akita T et al: Hepatitis B surface antigen seroprevalence among pre- and post-vaccine cohorts in Cambodia, 2017. Vaccine 2019, 37(35):5059-5066.

9. Sunbul M: Hepatitis B virus genotypes: global distribution and clinical importance. World journal of gastroenterology 2014, 20(18):5427-5434.

10. Huy TTT, Sall AA, Reynes JM, Abe K: Complete genomic sequence and phylogenetic relatedness of hepatitis B virus isolates in Cambodia. Virus Genes 2008, 36(2):299-305.

11. El Chaar M, Candotti D, Crowther RA, Allain JP: Impact of hepatitis B virus surface protein mutations on the diagnosis of occult hepatitis B virus infection. Hepatology 2010, 52(5):1600-1610.

12. Wu J-F, Ni Y-H, Chang M-H, Chiang C-L, Hsu H-Y, Chen H-L, Chen P-J: No Increase in Prevalence of Hepatitis B Surface Antigen Mutant in a Population of Children and Adolescents Who Were Fully Covered by Universal Infant Immunization. The Journal of Infectious Diseases 2010, 201(8):1192-1200.

13. Lumipulse FI, Japan: Report on HBsAg, HBsAb-N, HBcAb-N, HBeAg, HBeAb-N using Lumipulse G1200. In.; 2017.

14. Lange B, Roberts T, Cohn J, Greenman J, Camp J, Ishizaki A, Messac L, Tuaillon E, van de Perre P, Pichler C et al: Diagnostic accuracy of detection and quantification of HBV-DNA and HCV-RNA using dried blood spot (DBS) samples - a systematic review and meta-analysis. BMC infectious diseases 2017 , 17(Suppl 1):693-693. 
15. Fujimoto M, Chuon C, Nagashima S, Yamamoto C, Ko K, Svay S, Hok S, Lim O, Ohisa M, Akita T et al: A seroepidemiological survey of the effect of hepatitis B vaccine and hepatitis B and C virus infections among elementary school students in Siem Reap province, Cambodia. Hepatol Res 2018, 48(3):E172-E182.

16. Matsuo J, Do SH, Yamamoto C, Nagashima S, Chuon C, Katayama K, Takahashi K, Tanaka J: Clustering infection of hepatitis B virus genotype B4 among residents in Vietnam, and its genomic characters both intra- and extra-family. PloS one 2017, 12(7):e0177248-e0177248.

17. Yuasa R TK, Dien BV, Binh NH, Morishita T, Sato K, Yamamoto N, Isomura S, Yoshioka K, Ishikawa T, Mishiro S, Kakumu S: Properties of Hepatitis B virus Genome recovered from Vietnamese patients with fulminant hepatitis in comparison with those of acute hepatitis. Journal of Medical Virology 2000, 61(1):6.

18. lizuka H, Ohmura K, Ishijima A, Satoh K, Tanaka T, Tsuda F, Okamoto H, Miyakawa Y, Mayumi M: Correlation between Anti-HBc Titers and HBV DNA in Blood Units without Detectable HBsAg. Vox Sanguinis 1992, 63(2):107-111.

19. Nei M, Saitou N: The neighbor-joining method: a new method for reconstructing phylogenetic trees. Molecular Biology and Evolution 1987, 4(4):406-425.

20. Stecher G, Kumar S, Tamura K: MEGA7: Molecular Evolutionary Genetics Analysis Version 7.0 for Bigger Datasets. Molecular Biology and Evolution 2016, 33(7):1870-1874.

21. Lole KS, Bollinger RC, Paranjape RS, Gadkari D, Kulkarni SS, Novak NG, Ingersoll R, Sheppard HW, Ray SC: Full-Length Human Immunodeficiency Virus Type 1 Genomes from Subtype C-Infected Seroconverters in India, with Evidence of Intersubtype Recombination. Journal of Virology 1999, 73(1):152-160.

22. Schultz A-K, Bulla I, Abdou-Chekaraou M, Gordien E, Morgenstern B, Zoulim F, Dény P, Stanke M: jpHMM: recombination analysis in viruses with circular genomes such as the hepatitis B virus. Nucleic Acids Research 2012, 40(W1):W193-W198.

23. Krzywinski M, Schein J, Birol I, Connors J, Gascoyne R, Horsman D, Jones SJ, Marra MA: Circos: an information aesthetic for comparative genomics. Genome Res 2009, 19(9):1639-1645.

24. Purdy MA: Hepatitis B virus S gene escape mutants. Asian J Transfus Sci 2007, 1(2):62-70.

25. Hunt CM, McGill JM, Allen MI, Condreay LD: Clinical relevance of hepatitis B viral mutations. Hepatology 2000, 31(5):1037-1044.

26. Yamada H, Fujimoto M, Svay S, Lim O, Hok S, Goto N, Ohisa M, Akita T, Matsuo J, Do SH et al: Seroprevalence, genotypic distribution and potential risk factors of hepatitis B and C virus infections among adults in Siem Reap, Cambodia. Hepatology Research 2015, 45(4):480-487.

27. Bui TTT, Tran TT, Nghiem MN, Rahman P, Tran TTT, Dinh MNH, Le MH, Nguyen VVC, Thwaites G, Rahman M: Molecular characterization of hepatitis B virus in Vietnam. BMC Infectious Diseases 2017, 17(1):601

28. Olinger CM JP, Hübschen JM, et al. Possible New Hepatitis B Virus Genotype, Southeast Asia. Emerging Infectious Diseases. 2008;14(11):1777-1780. doi:10.3201/eid1411.080437.

29. Tangkijvanich P, Mahachai V, Komolmit P, Fongsarun J, Theamboonlers A, Poovorawan Y: Hepatitis B virus genotypes and hepatocellular carcinoma in Thailand. World journal of gastroenterology 2005, 11(15):2238-2243.

30. Louisirirotchanakul S, Olinger CM, Arunkaewchaemsri P, Poovorawan Y, Kanoksinsombat C, Thongme C, Sa-nguanmoo P, Krasae S, Theamboonlert A, Oota S et al: The distribution of hepatitis B virus genotypes in Thailand. Journal of Medical Virology 2012, 84(10):1541-1547.

31. Huy TT, Ushijima H, Win KM, Luengrojanakul P, Shrestha PK, Zhong ZH, Smirnov AV, Taltavull TC, Sata T, Abe K: High prevalence of hepatitis B virus pre-s mutant in countries where it is endemic and its relationship with genotype and chronicity. J Clin Microbio/ 2003, 41(12):5449-5455.

32. Chong-Jin O, Ning CW, Shiuan K, Keow LG: Identification of Hepatitis B Surface Antigen Variants with Alterations outside the "a" Determinant in Immunized Singapore Infants. The Journal of Infectious Diseases 1999, 179(1):259-263.

33. Poovorawan Y, Chongsrisawat V, Theamboonlers A, Leroux-Roels G, Crasta PD, Hardt K: Persistence and immune memory to hepatitis B vaccine 20 years after primary vaccination of Thai infants, born to HBsAg and HBeAg positive mothers. Human Vaccines \& Immunotherapeutics 2012, 8(7):896-904.

34. Meldal BHM, Bon AH, Prati D, Ayob Y, Allain JP: Diversity of Hepatitis B virus infecting Malaysian candidate blood donors is driven by viral and host factors. J Viral Hepatitis 2011, 18(2):91-101.

35. Hsu H-Y, Chang M-H, Liaw S-H, Ni Y-H, Chen H-L: Changes of hepatitis B surface antigen variants in carrier children before and after universal vaccination in taiwan. Hepatology 1999, 30(5):1312-1317.

36. Bes M, Vargas V, Piron M, Casamitjana N, Esteban JI, Vilanova N, Pinacho A, Quer J, Puig L, Guardia J et al: T cell responses and viral variability in blood donation candidates with occult hepatitis B infection. Journal of Hepatology 2012, 56(4):765-774.

37. Gencay M, Hübner K, Gohl P, Seffner A, Weizenegger M, Neofytos D, Batrla R, Woeste A, Kim H-S, Westergaard G et al: Ultra-deep sequencing reveals high prevalence and broad structural diversity of hepatitis B surface antigen mutations in a global population. PloS one 2017, 12(5):e0172101-e0172101.

38. Lee MH, Kim DY, Kim JK, Chang HY, Kang SH, Ryu HJ, Ju HL, Kim SU, Lee JM, Park JY et al: Combination of preS Deletions and A1762T/G1764A Mutations in HBV Subgenotype C2 Increases the Risk of Developing HCC. Intervirology 2012, 55(4):296-302.

39. Chuon C, Takahashi K, Matsuo J, Katayama K, Yamamoto C, Ko K, Hok S, Nagashima S, Akbar SMF, Tanaka J: High possibility of hepatocarcinogenesis in HBV genotype C1 infected Cambodians is indicated by $\mathbf{3 4 0 ~ H B V ~ C 1 ~ f u l l - g e n o m e s ~ a n a l y s i s ~ f r o m ~ G e n B a n k . ~ S c i e n t i f i c ~ R e p o r t s ~ 2 0 1 9 , ~ 9 ( 1 ) : 1 2 1 8 6 . ~}$

\section{Figures}




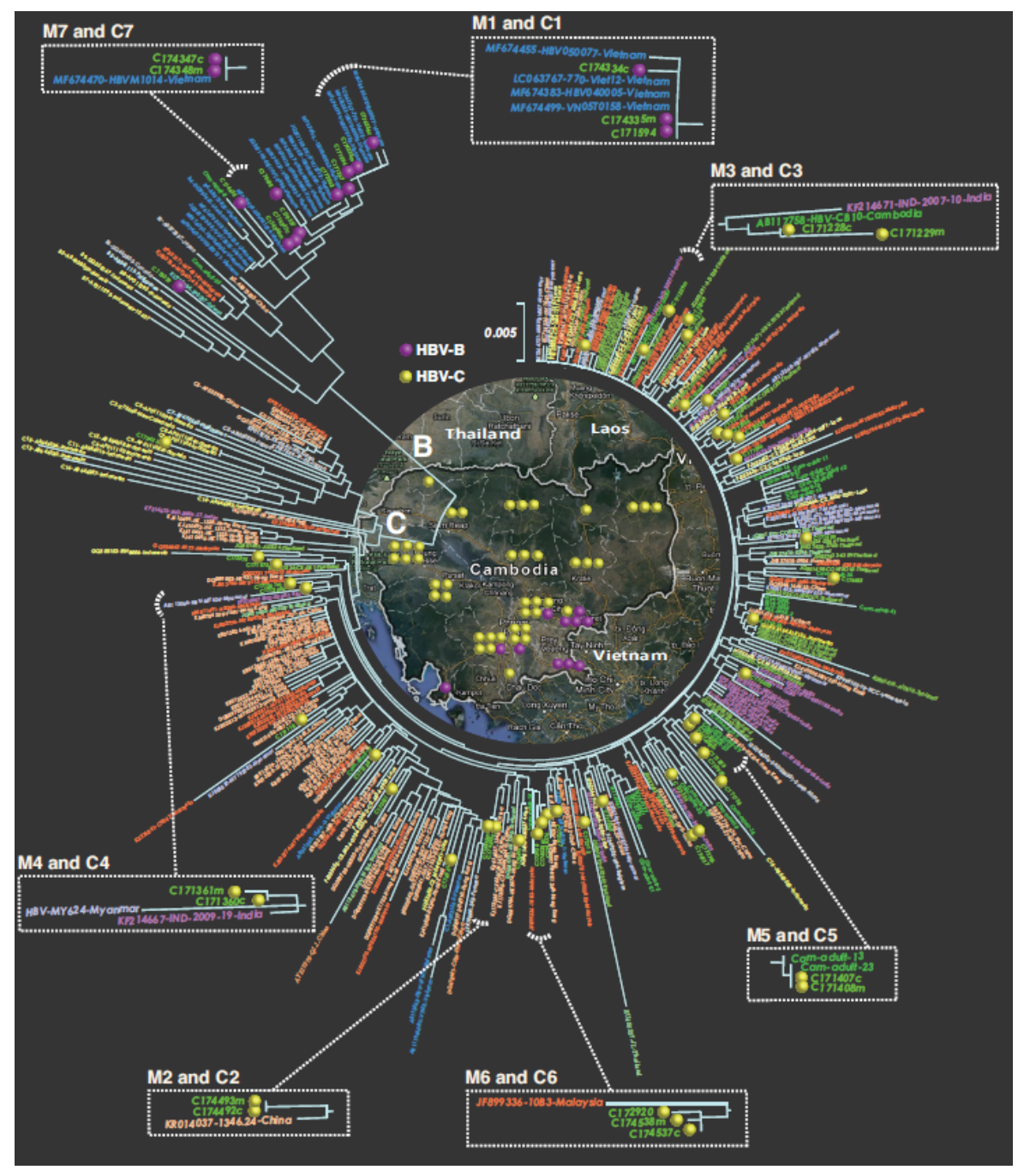

\section{Figure 1}

Countrywide genotype distribution of detected HBV strain from children and mothers in Cambodia. This figure shows the genotype distribution of the detected HBV strains among 5-7 years old children and their mothers in each province of Cambodia. HBV genotype B was represented by purple dot whereas HBV genotype $\mathrm{C}$ was indicated by yellow dot. 


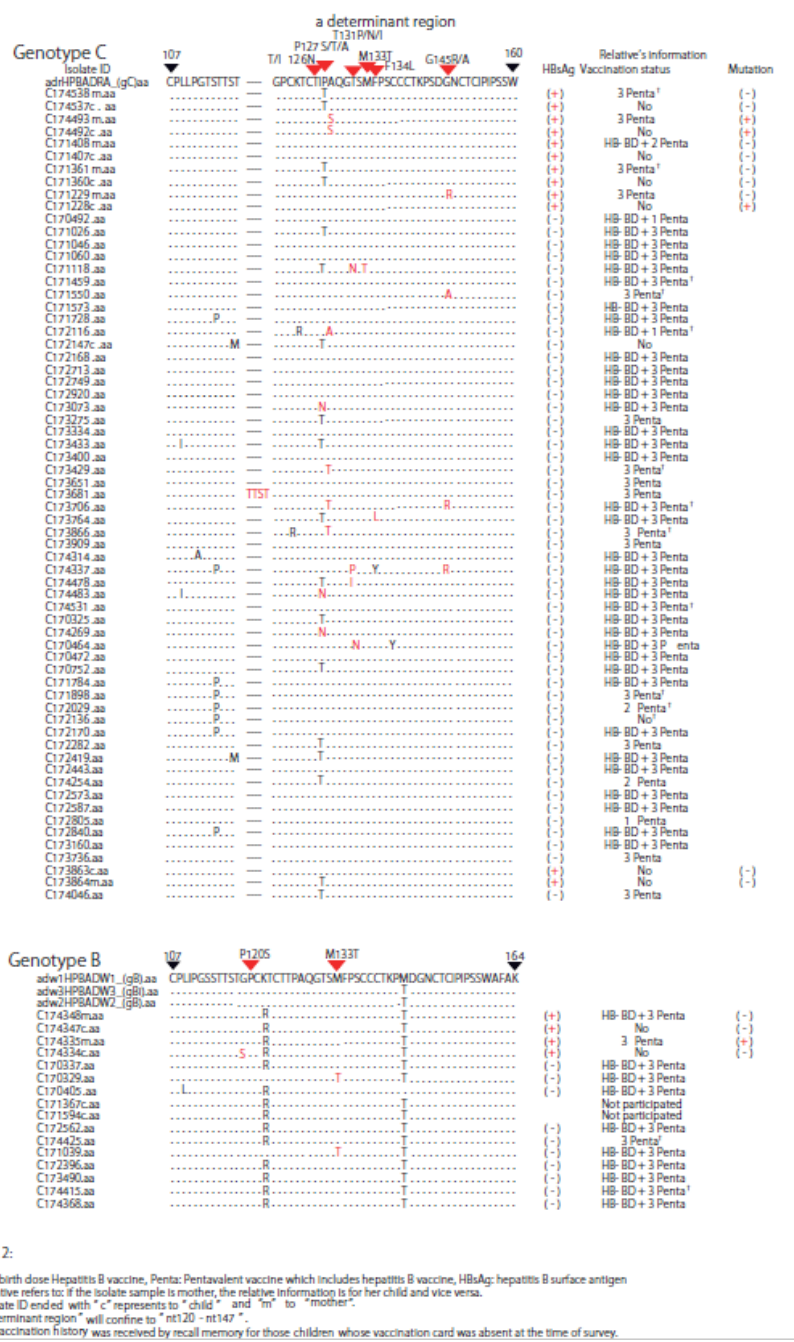

\section{Figure 2}

Hepatitis B surface protein mutation within a determinant region and its counterpart HBsAg and vaccination status. This figure shows the existence of hepatitis B surface protein mutation found within a determinant region from nt120-nt147 of either mother or child with additional HBsAg and vaccination status counterpart relatives. The relative refers to: if the isolate sample is mother, the relative information is for her child and vice versa. The isolate ID ended with "c" represents to "child" and " $m$ " to "mother". "a determinant region" will confine to "nt120-nt147". t: The vaccination history was received by recall memory for those children whose vaccination card was absent at the time of survey. 


\begin{tabular}{|c|c|c|c|c|}
\hline \multirow[t]{2}{*}{ Isolate ID } & Fragument & Breakpoint Interval & Fragment & Fragment \\
\hline & Start Position & Start-End & End Position & Genotype \\
\hline \multirow[t]{3}{*}{ C174334c } & 1 & $1733-1840$ & 1837 & B4 \\
\hline & 1838 & $2200-2451$ & 2241 & $\mathrm{C} 2$ \\
\hline & 2242 & & 3215 & B4 \\
\hline \multirow[t]{3}{*}{ C17335m } & 1 & $1733-1840$ & 1837 & B4 \\
\hline & 1838 & $2200-2453$ & 2241 & $\mathrm{C} 2$ \\
\hline & 2242 & & 3215 & B4 \\
\hline \multirow[t]{3}{*}{ C174347c } & 1 & $1738-1840$ & 1837 & B4 \\
\hline & 1838 & $2189-2546$ & 2196 & $\mathrm{C} 2$ \\
\hline & 2197 & & 3215 & B4 \\
\hline \multirow[t]{3}{*}{ C174348m } & 1 & $1738-1840$ & 1837 & B4 \\
\hline & 1838 & $2189-2546$ & 2196 & $\mathrm{C} 2$ \\
\hline & 2197 & & 3215 & B4 \\
\hline \multirow[t]{3}{*}{ C170329 } & 1 & $1760-1840$ & 1837 & B2 \\
\hline & 1838 & 2199-2285 & 2232 & $\mathrm{C} 2$ \\
\hline & 2233 & & 3215 & B2 \\
\hline \multirow[t]{3}{*}{ C170337 } & 1 & $1733-1840$ & 1837 & B4 \\
\hline & 1838 & $2200-2455$ & 2241 & $\mathrm{C} 2$ \\
\hline & 2242 & & 3215 & B4 \\
\hline \multirow[t]{3}{*}{ C170405 } & 1 & $1756-1809$ & 1809 & B4 \\
\hline & 1810 & $2199-2212$ & 2199 & $\mathrm{C} 2$ \\
\hline & 2200 & & 3215 & B4 \\
\hline \multirow[t]{3}{*}{ C171367 } & 1 & $1757-1864$ & 1861 & B4 \\
\hline & 1862 & $2213-2468$ & 2220 & $\mathrm{C} 2$ \\
\hline & 2221 & & 3239 & B4 \\
\hline \multirow[t]{3}{*}{ C171594 } & 1 & $1733-1840$ & 1837 & B4 \\
\hline & 1838 & $2200-2453$ & 2241 & $\mathrm{C} 2$ \\
\hline & 2242 & & 3215 & B4 \\
\hline \multirow[t]{3}{*}{ C172562 } & 1 & $1733-1840$ & 1837 & B4 \\
\hline & 1838 & $2199-2566$ & 2226 & $\mathrm{C} 2$ \\
\hline & 2227 & & 3215 & B4 \\
\hline \multirow[t]{3}{*}{ C174425 } & 1 & $1733-1840$ & 1837 & B4 \\
\hline & 1838 & $2200-2453$ & 2241 & $\mathrm{C} 2$ \\
\hline & 2242 & & 3215 & B4 \\
\hline
\end{tabular}
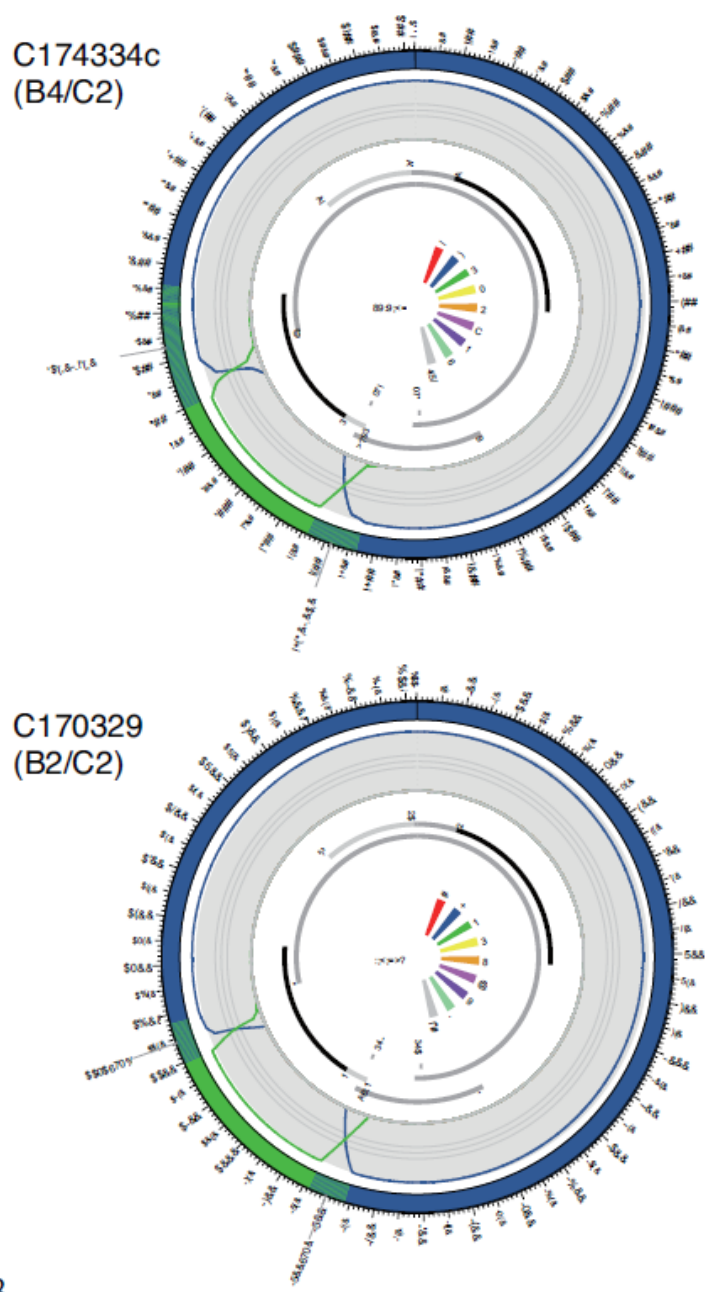

Figure 3

\section{Figure 3}

Structural model for Recombinant HBV genomes of this study. The figure shows the recombinant HBV genomes found in this study. The starting points and breaking points are shown in left side table. $11 \mathrm{HBV}$ genotype B strains were enrolled for the detection of recombinant HBV genomes using jpHMM software. The structural configurations of the detected HBV recombinant genomes are shown in right figures; the upper one for recombinant B4/C2 and the lower one for recombinant B2/C2. 